\title{
ANALISIS PENGARUH PEMBERDAYAAN KARYAWAN TERHADAP KEPUASAN KERJA DI PT SDV LOGISTIC
}

\author{
Francisca Hermawan \\ Eric Chandra \\ Universitas Katolik Indonesia Atma Jaya \\ e-mail: franciscahermawan@yahoo.com
}

\begin{abstract}
ABSTRACK
Human resource development, knowledge and technology hold an important role in reaching company goal, therefore employee empowerment to perform well needs to be maximally implemented. This research is made to find out if there is any significant impact between employee empowerment and job satisfaction at PT SDV logistic. There are 3 variables used in this empowerment: meaning, self-determination, and impact. Datas used in this research are premier datas with questionnaires and secondary datas obtained from the company. Population in this research is all PT SDV Logistic employees and number of sampling used is 50 respondents, using convenience sampling method. Research result shows that employee empowerment has simultaneous impact to job satisfaction, but partially has no impact on job satisfaction.
\end{abstract}

Keywords: employee empowerment, meaning, self-determination,impact and job satisfaction.

\section{PENDAHULUAN}

Karyawan sebagai salah satu faktor produksi perusahaan dan aset perusahaan yang menjadi unsur investasi efektif perusahaan, karena hal tersebut kualitas mereka perlu dikembangkan dan dipelihara melalui pemberdayaan pada individu dan kelompok karyawan secara berkelanjutan. Pemberdayaan dalam penelitian pada perusahaan PT SDV Logistic tidak hanya dalam bentuk pelatihan dan pengembangan tetapi lebih bermakna sebagai refleksi proses demokrasi di tubuh perusahaan yakni dengan melibatkan karyawan dalam pengambilan keputusan organisasi.

Kemampuan karyawan dapat berhubungan dengan kualitas pekerjaan; kebebasan melaksanakan pekerjaan dan pengaruh individu terhadap pengambilan keputusan dalam permasalahan yang dihadapi perusahaan.Pola perilaku karyawan perlu diubah dengan pemberdayaan karyawan sehingga meningkatkan kepuasaan kerja dan berdampak pada kinerja karyawan pada perusahaan.Pemberdayaan karyawan terkait dengan teknik dan instrument seperti: motivasi, komunikasi, kepercayaan, pendelegasian, training dan feedback, job enrichment. Instrumen-instrumen ini yang membuat seorang manajer melakukan analisa hal-hal yang perlu diberdayakan dari berbagai perspektif.

Pemberdayaan menurut Hales dan Klidas (2008) adalah suatu proses pendelegasi otoritas atasan kepada bawahan di dalam organisasi. Untuk dapat mendelegasikan otoritas, pemimpin perlu memberikan pengetahuan kepada bawahan mengenai cara melaksanakan suatu pekerjaan 
yang didelegasikan dan menjelaskan bahwa pekerjaan tersebut membantu meningkatkan kinerja karyawan dan tercapainya misi perusahaan. Sedangkan kepuasan kerja menurut Noe et al (2007) adalah perasaan senang atas hasil kerja yang telah diselesaikan oleh karyawan. Tinggi rendahnya kepuasan kerja sangat tergantung pada sejumlah faktor antara lain seberapa besar keinginan seseorang dapat dipenuhi melalui pekerjaan yang dilakukannya dan juga tergantung kepada sikap dan nilai yang dianutnya masing-masing. Berdasarkan adanya pemberdayaan yang dapat dikaitkan dengan kepuasaan karyawan maka peneliti mencoba mengkaji beberapa hal, yaitu apakah terdapat pengaruh yang signifikan antara pemberdayaan karyawan berdasarkan dimensi meaning terhadap kepuasan karyawan PT SDV Logistic Indonesia?, apakah terdapat pengaruh yang signifikan antara pemberdayaan karyawan berdasarkan dimensi influence terhadap kepuasaan karyawan PT SDV Logistic Indonesia?, apakah terdapat pengaruh yang signifikan antara pemberdayaan karyawan berdasarkan dimensi Self-determination terhadap kepuasaan karyawan PT SDV Logistic Indonesia? Pada pembahasan penelitian ini penulis membatasi permasalahan dalam objek penelitian yaitu pada PT SDV Logistic Indonesia sedangkan subjeknya adalah pegawai tetap yang ada pada PT SDV Logistic Indonesia. Penelitian ini dibuat agar perusahaan mengetahui apakah terdapat pengaruh yang signifikan antara pemberdayaan karyawan terhadap kepuasan karyawan secara parsial maupun simultan.

\section{REVIEW LITERATUR DAN HIPOTESIS}

\section{Pemberdayaan Karyawan}

Dalam manajemen sumber daya manusia terdapat beragam definisi mengenai pemberdayaan karyawan. Menurut Noe et al (2010) manajemen sumber daya manusia merupakan kebijakan, praktisi dan sistem yang mempengaruhi perilaku, tindakan, dan kinerja karyawan. Sedangkan menurut Ivancvich (2007) sumber daya manusia sebagai fungsi didalam organisasi dengan memfasilitasikan orang-orang yang efektif didalam organisasi untuk mencapai tujuan perusahaan dan tujuan individu.

Maju mundurnya perkembangan suatu perusahaan sangat dipengaruhi oleh jumlah dan mutu karyawannya. Karyawan diposisikan sebagai aset perusahaan. Sekaligus sebagai unsur investasi efektif perusahaan. Karena itu mutu mereka perlu dikembangkan dan dipelihara melalui pemberdayaan pada individu dan kelompok karyawan secara berkelanjutan. Pemberdayaan disini tidaklah hanya dalam bentuk pelatihan dan pengembangan, tetapi dalam perspektif yang lebih luas pemberdayaan juga bermakna sebagai refleksi adanya proses demokrasi di tubuh perusahaan yakni dengan melibatkan karyawan dalam pengambilan keputusan organisasi.

Selain pemberdayaan ada istilah pengembangan partisipasi karyawan yang kedengarannya bermakna sama namun dalam beberapa segi ternyata memiliki perbedaan. Partisipasi selama ini diartikan sebagai bagian tak terpisahkan dari pemberdayaan karyawan. Partisipasi berarti terjadinya konsultasi, terbukanya kegiatan berbagi opini dan keputusankeputusan karyawan. Istilah partisipasi juga sangat erat kaitannya dengan model manajemen kemitraan. Dalam model manajemen ini, karyawan dipandang sebagai mitra kerja ketimbang sebagai subordinasi dari superordinasi.

Menurut Conger and Kanungo (2008) Pemberdayaan merupakan salah satu konsep motivasi yang behubungan dengan efikasi diri karyawan (self-efficacy) dan pemberdayaan dipercaya akan dapat meningkatkan efikasi diri karyawan didalam perusahaan. Tingkat efikasi diri individu satu dengan individu lainnya berbeda. Apabila seseorang memiliki tingkat efikasi yang tinggi maka dia selalu yakin dengan kemampuan yang dimiliki untuk melakukan suatu tugas 
perusahaan, sedangkan seseorang yang memiliki tingkat efikasi dirinya rendah maka ia ragu dalam menyelesaikan tugasnya. Jadi meningkatnya tingkat efikasi diri seorang karyawan , maka pimpinan perusahaan dapat menetapkan target yang lebih tinggi padanya.

Menurut Hennestad et al (2011) karyawan dikatakan diberdayakan jika pemimpin melakukan pendelegasian kepada karyawan dan mengikut sertakannya kedalam proses pengambilan keputusan dari tingkat atas ke tingkat bawah organisasi.

Unsur Pemberdayaan menurut Agusta (2012) ada 3 unsur yaitu: pertama Pendidikan, meliputi memahami kebutuhan, membimbing, melatih, konsultasi, mengajarkan, dan mendelegasikan tugas-tugas yang menantang bagi perkembangan karyawan. Kedua, memberi kesempatan dengan berbagi tanggung jawab, mengijinkan eksperimen dan mendelegasikan wewenang dan tanggung jawab. Ketiga, memotivasi, mempercayai dan mendorong inovasi, ide dan resiko karyawan. Serta memberikan pekerjaan yang bermakna sehingga menimbulkan tantangan dan variasi. Selain itu motivasi juga dapat dilakukan dengan menghargai dan mendorong pencapaian tugas dan meminta umpan balik.

Pendekatan Pemberdayaan menurut Newstrorm dan Davis (2002) ada lima pendekatan pemberdayaan karyawan, yaitu :

1. membantu karyawan untuk memperoleh penguasan atas pekerjaannya, memberikan pelatihan yang layak, bimbingan dan pengarahan yang sesuai.

2. Memberikan lebih banyak keleluasaan, memberi karyawan kebebasan atas pekerjaannya dan membuat mereka bertanggung jawab atas hasilnya.

3. Memberikan contoh pelaksanaan tugas yang sukses, memperbolehkan karyawan mengamati rekan kerja yang sudah melaksanakan pekerjaan dengan baik.
4. Menggunakan motivasi dan bujukan sosial, memberikan pujian, dorongan dan umpan balik secara verbal untuk meningkatkan kepercayaan diri.

5. Memberikan dukungan emosional, mengurangi stress dan kegelisahan dengan memberikan tugas yang jelas, memberikan bantuan dalam pelaksanaan tugas serta perhatian yang tulus.

\section{Kepuasan Kerja}

Menurut Schermerhorn (2010) kepuasan kerja adalah perasaan negatif dan positif setiap karyawan mengenai pekerjaannya. Jadi karyawan yang puas akan bekerja sesuai dengan ekspektasi perusahaan dan akan menghasilkan kinerja yang baik. Sebaliknya jika karyawan tidak puas ia akan sering tidak hadir dan bekerja dengan malas-malasan.

Peneliti seperti Greenberg dan Baron (2008) menjelaskan bahwa kepuasan kerja adalah sikap positif atau negatif seorang karyawan terhadap pekerjaannya. Perilaku karyawan didalam perusahaan ditentukan oleh kepuasan kerja seorang karyawan. Jika ia puas terhadap pekerjaanya maka perilaku yang ditunjukan adalah perilaku positif sedangkan jika ia merasa tidak puas maka perilaku yang ditunjukan adalah perilaku negative. Sedangkan Noe (2008: 462) menyatakan bahwa kepuasan kerja adalah suatu perasaan menyenangkan yang dihasilkan dari persepsi bahwa pekerjaan seseorang memenuhi atau memungkinkan untuk pemenuhan nilai-nilai penting pekerjaan.

Menurut Kreitner dan Kinicki (2010) ada beberapa hal yang menjadi terciptanya kepuasan kerja, yaitu:

1. Pemenuhan kebutuhan

Kepuasan kerja ditentukan oleh sejauh mana karakteristik pekerjaan dapat memenuhi kebutuhan setiap individu. Maka tingkat kepentingan suatu pekerjaan dan harapan atas pekerjaannya itu terpenuhi. 
2. Perbedaan

Perbedaan ini berkaitan dengan harapanharapan yang saling bertemu. Jadi adanya perbedaan tentang ekspektasi seorang karyawan dengan apa yang sesungguhnya diterima karyawan.

3. Pencapaian nilai

Rasa puas yang berasal dari persepsi karyawan mengenai pencapaian atas pekerjaan yang telah dicapainya.

4. Persamaan

Persamaan perlakukan pada tempat kerja sangat menentukan kepuasan kerja seorang karyawan. karena apabila organisasi berlaku secara tidak adil maka karyawan tidak akan merasa puas.

5. Dispositional

Perilaku individu yang disebabkan oleh karakteristik internal.

Menurut Rivai dan Sagala (2010), menyatakan beberapa teori yang berkaitan dengan kepuasan kerja, antara lain: pertama, Teori ketidakpuasan (Discrepancy Theory), teori yang mengukur kepuasan kerja karyawan dengan menghitung selisih antara sesuatu yang seharusnya dengan kenyataan yang dirasakan. Sehingga apabila kepuasaan yang diperoleh melebihi dari yang diinginkan maka orang akan menjadi lebih puas lagi sehingga terdapat discrepancy tetapi bersifat positif. Kedua, teori Keadilan (equity Theory), teori ini mengemukakan bahwa orang akan merasa puas atau tidak puas tergantung pada ada atau tidaknya keadilan ( equity) dalam suatu situasi kerja. Komponen utama dalam teori ini adalah input, hasil, keadilan dan ketidakadilan. Ketiga, teori dua factor (Two factor theory), mengemukakan bahwa kepuasan kerja dan ketidakpuasan kerja bukan seuatu variable yang kontinu. Karakteristik pekerjaan dalam teori ini ada dua yaitu satisfies dan dissatisfies. Satisfies adalah faktorfaktor yang dibutuhkan sebagai sumber kepuasan kerja seperti: pekerjaan yang menarik, penuh tantangan, kesempatan berprestasi, memperoleh penghargaan dan promosi. Terpenuhinya faktorfaktor tersebut menimbulkan kepuasan, tetapi jika tidak terpenuhi menimbulkan ketidakpuasaan. Dissatisfies (hygine factors) adalah faktor-faktor yang menjadi sumber ketidakpuasaan, terdiri dari: gaji, pengawasan, hubungan antar pribadi ,kondisi kerja dan status. Jika factor-faktor tersebut tidak terpenuhi maka karyawan tidak puas, namun jika terpenuhi , karyawan senang.

\section{Model Penelitian}

\section{Gambar 1. Model Penelitian}

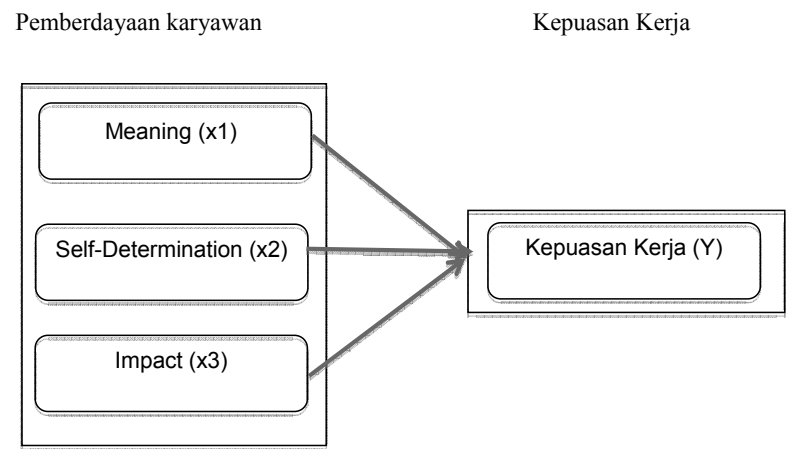

Hipotesis yang diajukan dalam penelitian ini, penulis menggunakan hipotesis kausal yang menyatakan ada atau tidaknya perubahan suatu variabel yang diakibatkan oleh variable lain. Hipotesis dalam penelitian ini adalah sebagai berikut:

$\mathrm{H}_{1} \quad$ : Meaning berpengaruh secara signifikan terhadap kepuasan kerja

$\mathrm{H}_{2} \quad$ : Self-determination berpengaruh secara signifikan terhadap kepuasan kerja

$\mathrm{H}_{3} \quad$ : Impact berpengaruh secara signifikan terhadap kepuasan kerja

$\mathrm{H}_{4} \quad$ : Meaning, Self-determination, dan Impact secara bersama-sama berpengaruh signifikan terhadap kepuasan kerja. 


\section{METODE PENELITIAN}

Definisi operasional menurut Bougie dan Sekaran (2010) merupakan aturan dalam pengukuran dengan mempersempit tingkat abstrak menjadi dimensi dan elemen.

Objek penelitian yang digunakan dalam penelitian ini adalah karyawan dari divisi operasional pada PT SDV Logistic Indonesia yang berjumlah 96 karyawan dilaksanakan pada Oktober 2012 sampai Januari 2013 dan teknik pengambilan sampel yang digunakan dengan convenience sampling yaitu sampling nonprobability yang diambil dari populasi sampel yang sudah tersedia dan nyaman. Peneliti mendapatkan sampel berjumlah 50 karyawan tetap pada divisi operasional PT SDV Logistic Indonesia. Pengambilan sampel mengacu pada teori Roscoe dalam Suparmono (2004), mengenai rules of thumb yang menyatakan bahwa ukuran sampel yang ideal berkisar antara 30-500 responden. Teknik ini dipilih peneliti karena lebih cepat dan efisien untuk mendapatkan informasi dari responden.

\section{HASIL PENELITIAN DAN PEMBAHASAN}

Peneliti mempergunakan metode analisis deskriptif dan analisa kuantitatif. Analisa deskriptif digunakan untuk menentukan karakteristik responden berdasarkan jenis kelamin, usia, pendidikan dan masa kerja dari karyawan. Responden yang diambil laki-laki dan perempuan berjumlah 50 orang yang terdiri dari $48 \%$ adalah Laki-laki dan 52\% adalah perempuan. Usia responden dibawah 20 tahun sampai dengan diatas 35 tahun. Hampir semua responden di perusahaan tersebut masih relatif baru dapat dikatakan demikian karena $84 \%$ responden baru bekerja selama maksimal 5 tahun, mempunyai tingkatan pendidikan sarjana (S1) berjumlah 31 responden, responden yang memiliki tingkat pendidikan diploma sebesar 12 responden dan sisanya pendidikan sekolah menengah umum. Sedangkan Uji statistic yang dilakukan peneliti yaitu uji validitas, realiabilitas dan analisis regresi linier berganda yang meliputi analisis korelasi ganda $(\mathrm{R})$, analisis determinasi $\left(\mathrm{R}^{2}\right)$, uji koefisien regresi secara simultan (uji F), uji koefisien regresi secara parsial (uji T) dan uji signifikansi.

Tabel 1.

Overall Mean Score

\begin{tabular}{llll}
\hline \multicolumn{1}{c}{ Variabel } & \multicolumn{1}{c}{ Oms } & Klasifikasi & \multicolumn{1}{c}{ Kategori } \\
\hline $\begin{array}{l}\text { Dimensi Meaning } \\
\text { Dimensi Self- }\end{array}$ & 4.30 & $4.21-5.00$ & Sangat Tinggi \\
Determination & 3.60 & $3.41-4.20$ & Tinggi \\
Dimensi Impact & 3.455 & $3.41-4.20$ & Tinggi \\
Kepuasan Kerja & 3.28 & $2.61-3.40$ & Netral \\
\hline
\end{tabular}

Sumber: hasil olah data

Tabel 1 menunjukkan dimensi meaning berada pada kategori sangat tinggi, artinya pekerjaan sangat berarti tinggi bagi karyawan. Dimensi self-determination berada pada kategori tinggi, artinya karyawan mempunyai kebebasan melaksanakan pekerjaan cukup tinggi. Dimensi impact berada pada kategori tinggi, artinya pengaruh karyawan pada perusahaan cukup tinggi. Sedangkan kepuasan kerja berada pada kategori netral, artiya kepuasan karyawan secara emosional terhadap pekerjaannya cukup.

Tabel 2.

Koefisien Korelasi

\begin{tabular}{llllll}
\hline & & $\begin{array}{c}\text { X1 } \\
\text { Meaning }\end{array}$ & $\begin{array}{c}\text { X2 Self } \\
\text { Determination }\end{array}$ & $\begin{array}{c}\text { X3 } \\
\text { Impact }\end{array}$ & Y \\
\hline \multirow{4}{*}{ X1 Meaning } & Person & 1 & .251 & .186 & $331^{*}$ \\
& correlation & & .079 & .195 & .019 \\
X2 Self & Sig. (2-tailed) & & 50 & 50 & 50 \\
& N & 50 & 1 & .308 & $.341^{*}$ \\
Determination & Pearson & .251 & 1 & .029 & .015 \\
& Correlation & .079 & & 50 & 50 \\
& Sig. (2-tailed) & .079 & 50 & 1 & .273 \\
& N & 50 & & & $.308^{*}$ \\
& Pearson & .186 & .029 & & .055 \\
& Correlation & & & & \\
& Sig. (2-tailed) & .195 & 50 & 50 & 50 \\
& N & 50 & $.341^{*}$ & .273 & 1 \\
& Pearson & $.331^{*}$ & .015 & .055 & \\
& Correlation & .019 & 50 & 50 & \\
& Sig. (2-tailed) & .019 & & &
\end{tabular}

Sumber: hasil olah data 
Tabel 2 menunjukkan nilai koefisien korelasi ini menjelaskan tentang hubungan setiap dimensi terhadap kepuasan kerja. Pada dimensi meaning mempunyai nilai koefisien korelasi sebesar 0.331 . Artinya, terdapat hubungan positif dan signifikan pada level (0.05) antara meaning dan kepuasan kerja. Sedangkan pada dimensi Self-determination juga diperoleh nilai koefisien korelasi sebesar 0.341. Artinya, terdapat hubungan positif dan signifikan pada level (0.05) antara Self-determination dan kepuasan kerja. Pada dimensi Impact nilai koefisien korelasi juga diketahui sebesar 0.55 antara Impact dan kepuasan kerja. Artinya, terdapat hubungan negatif dan tidak signifikan pada level (0.05).

\section{Tabel 3}

Nilai R Square

Model Summary

\begin{tabular}{lcccc}
\hline Model & $\mathrm{R}$ & R Square & Adjusted R Square & $\begin{array}{c}\text { Std. Error of the } \\
\text { Estimate }\end{array}$ \\
\hline 1 & $.450^{\mathrm{a}}$ & .202 & .150 & .677927 \\
\hline a. & $\begin{array}{l}\text { Predictors: (Constant), X3(Impact), X1 (Meaning), } \\
\text { X2(Self-Determination) }\end{array}$ \\
Sumber: hasil olah data
\end{tabular}

Dari tabel 3 dapat diketahui bahwa nilai koefisien $R$ Square menunjukkan angka 0.202 atau sama dengan $20.2 \%$. Variabel meaning (X1), variabel self-determination (X2); dan variable impact (X3) dapat menjelaskan perubahan kepuasan kerja, sedangkan sisanya dipengaruhi oleh faktor lain selain pemberdayaan karyawan seperti Job Involvement, Job Enrichment, Job Enlargement, Performance, Motivation, yang tidak diteliti dalam penelitian ini.

\section{Tabel 4}

Uji F

\begin{tabular}{|c|c|c|c|c|c|c|}
\hline \multicolumn{7}{|c|}{$\mathrm{ANOVA}^{\mathrm{a}}$} \\
\hline Model & & $\begin{array}{l}\text { Sum of } \\
\text { Squares }\end{array}$ & $\mathrm{Df}$ & $\begin{array}{l}\text { Mean } \\
\text { Square }\end{array}$ & $\mathrm{F}$ & Sig. \\
\hline \multirow{3}{*}{1} & Regression & 5.364 & 3 & 1.788 & 3.891 & $.015^{\mathrm{b}}$ \\
\hline & Residual & 21.141 & 46 & .460 & & \\
\hline & Total & 26.505 & 49 & & & \\
\hline
\end{tabular}

a. Dependent Variable: Y4

b. Predictors: (Constant), X3 (Impact), X1 (Meaning), X2 (Self-Determination)

Sumber: hasil olah data
Pada tabel 4 dijelaskan bahwa secara bersama-sama/simultan, pemberdayaan karyawan mempengaruhi kepuasan kerja dalam nilai sebesar 3.891 dan tingkat signifikan sebesar 0.015. Tingkat signifikansi ini dapat dikatakan signifikan karena kurang dari 0.05 .

$\mathrm{H} 0=\beta 1=\beta 2=\beta 3=0 \rightarrow$ Pemberdayaan karyawan secara bersama-sama mempengaruhi kepuasan kerja

$\mathrm{H} 0 \neq \beta 1 \neq \beta 2 \neq \beta 3 \neq 0 \rightarrow$ Pemberdayaan karyawan secara bersama-sama tidak mempengaruhi kepuasan kerja

Tabel 5

Uji Parsial

Coefficients $^{\mathrm{a}}$

\begin{tabular}{|c|c|c|c|c|c|c|}
\hline & \multirow{2}{*}{ Model } & \multicolumn{2}{|c|}{$\begin{array}{l}\text { Unstandardized } \\
\text { Coefficients }\end{array}$} & \multirow{2}{*}{$\begin{array}{c}\begin{array}{c}\text { Standardized } \\
\text { Coefficients }\end{array} \\
\text { Beta }\end{array}$} & \multirow{2}{*}{$\mathrm{t}$} & \multirow{2}{*}{ Sig. } \\
\hline & & B & Std. Error & & & \\
\hline \multirow{4}{*}{1} & (Constant) & .833 & .870 & & .958 & .343 \\
\hline & X1 (Meaning) & .327 & .184 & .244 & 1.782 & .081 \\
\hline & $\begin{array}{l}\text { X2 (Self- } \\
\text { Determination) }\end{array}$ & .241 & .148 & .232 & 1.637 & .109 \\
\hline & X3 (Impact) & .165 & .147 & .156 & 1.119 & .269 \\
\hline
\end{tabular}

Sumber: hasil olah data

Diketahui bahwa dimensi meaning memiliki p-value sebesar $0.081>0.05$ dan memiliki nilai $\mathrm{t}$ hitung $1.782<$ nilai $\mathrm{t}$ tabel 2.0096. Artinya H01 tidak ditolak pemberdayaan dimensi meaning tidak mempunyai pengaruh yang signifikan terhadap kepuasan kerja. Dimensi Self-Determination memiliki p-value sebesar $0.109>0.05$ dan memiliki nilai t hitung 1.637 $<$ nilai t tabel 2.0096. Artinya H03 tidak ditolak pemberdayaan dimensi self-determination tidak mempunyai pengaruh yang signifikan terhadap kepuasan kerja. Dimensi Impact memiliki p-value sebesar $0.269>0.5$ dan memiliki nilai $t$ hitung $1.119<$ nilai t tabel 2.0096. Artinya H04 tidak ditolak pemberdayaan dimensi impact tidak mempunyai pengaruh yang signifikan terhadap kepuasan kerja.

1. Ho $=\beta 1=0 \rightarrow$ tidak terdapat pengaruh meaning terhadap kepuasan kerja 
Ho $=\beta 1 \neq 0 \rightarrow$ terdapat pengaruh meaning terhadap kepuasan kerja

2. Ho $=\beta 2=0 \rightarrow$ tidak terdapat pengaruh self-determination terhadap kepuasan kerja

$\mathrm{H} 0=\beta 2 \neq 0 \rightarrow$ terdapat pengaruh selfdetermination terhadap kepuasan kerja

3. $\mathrm{HO}=\beta 3=0 \rightarrow$ tidak terdapat pengaruh impact terhadap kepuasan kerja

$\mathrm{HO}=\beta 3 \neq 0 \rightarrow$ terdapat pengaruh impact terhadap kepuasan kerja

Berdasarkan hasil regresi yang dilakukan dapat diketahui bahwa pemberdayaan dimensi meaning dalam penelitian ini tidak memiliki pengaruh yang signifikan terhadap kepuasan kerja. Hal ini disebabkan karena sebagian besar responden memang merasa bahwa pekerjaan yang dilakukan sangat penting dan berarti baginya dilihat dari usia responden.

Pemberdayaan dimensi Self-determination juga dapat diketahui bahwa tidak memiliki pengaruh yang signifikan karena sebagian karyawan merasa mereka bekerja sesuai dengan perintah dari atasan.

Pemberdayaan dimensi Impact perusahaan juga dapat diketahui bahwa tidak memiliki pengaruh yang signifikan karena sebagian besar karyawan merasa keputusan yang diambil adalah keputusan dari atasan dan tidak melibatkan pendapat bawahan sehingga dimensi impact tidak bersignifikansi dengan kepuasan kerja.

Koefisien korelasi antara dimensi meaning dan kepuasan kerja sebesar 0.331. Artinya, terdapat hubungan positif dan signifikan antara meaning dan kepuasan kerja untuk alpha sebesar $5 \%$. Selain itu pada dimensi self-determination juga diperoleh nilai koefisien korelasi sebesar 0.341. Artinya, terdapat hubungan positif dan signifikan pada level (0.05) antara Selfdetermination dan kepuasan kerja. Sedangkan nilai koefisien korelasi antara Impact dan kepuasan kerja sebesar 0.55. Artinya, hubungan negatif dan tidak signifikan pada level (0.05) antara impact dan kepuasan kerja.

Dari hasil tersebut dapat dilihat bahwa variabel meaning dan self-determination memiliki hubungan positif sedangkan dimensi impact memiliki hubungan negatif terhadap kepuasan kerja. Hal tersebut dapat dilihat dari nilai koefisien korelasi dan juga dari setiap kenaikan variabel $\mathrm{X}$ akan diikuti dengan kenaikan variabel $\mathrm{Y}$ dengan hasil regresi sebagai berikut $\mathrm{Y}=0.833+$ $0.327 \mathrm{X} 1+0.241 \mathrm{X} 2+0.165 \mathrm{X} 3$.

\section{KESIMPULAN DAN SARAN}

\section{Kesimpulan}

Berdasarkan penelitian dari hasil analisis perhitungan mean score dan overall mean score dari variabel pemberdayaan, dapat diketahui bahwa pemberdayaan berada pada kategori tinggi, hal ini ditunjukan dengan nilai overall mean score sebesar 3.785 termasuk dalam interval 3.41-4.20Sehingga dapat disimpulkan bahwa semua karyawan sudah merasa diberdayakan oleh perusahaan. Hasil analisis perhitungan mean score variabel kepuasan kerja berada pada kategori cukup tinggi dengan nilai overall mean score sebesar 3.28 yang masuk kedalam interval 2.61-3.40, Sehingga dapat diketahui bahwa dalam PT SDV memiliki kepuasan kerja yang cukup. Dari hasil analisis regresi berganda menunjukan besarnya koefisin penentu 0,202 atau sama dengan $20.2 \%$, artinya sebesar $20,2 \%$ variabel pemberdayaan dapat menjelaskan variabel peningkatan kepuasan kerja dan sisanya $79.8 \%$ dapat dijelaskan oleh faktor yang lain. Selain itu dari koefisien yang diperoleh tersebut dapat diketahui persamaan regresi berganda yaitu: $\mathrm{y}=0,833+0,327 \mathrm{X} 1+0,241 \mathrm{X} 2+0,165 \mathrm{X} 3$, artinya bahwa setiap kenaikkan satu point pada variabel meaning, self-determination dan impact akan menambah kepuasan kerja karyawan sebesar 0,$327 ; 0,241 ;$ dan 0,165 . Hal ini terbukti dengan penelitian sebelumnya yang dilakukan oleh Elbeyi 
Pelit, Yuksel Ozturk dan Yalcin Arslanturk dari International Jornal of Contemporary Hospitality Management vol.23 no.6, tahun 2011 dengan topik "The Effect of Employee Empowerment on Employee Job Satisfaction" yaitu pemberdayaan dimensi meaning, self-determination dan impact secara simultan mempengaruhi kepuasan kerja karyawan.

\section{Saran}

Berdasarkan hasil penelitian di PT SDV Logistic, peneliti dapat memberikan saran yang berkaitan dari perolehan hasil uji $\mathrm{T}$ dimana model variabel independen secara parsial tidak berpengaruh signifikan terhadap variabel dependen, tetapi secara simultan dengan uji $\mathrm{F}$ diperoleh hasil berpengaruh signifikan. Untuk hal itu peneliti menyarankan perlu dilakukan penelitian selanjutnya dengan menambah faktor atau variabel independen yang mempengaruhi kepuasan kerja seperti motivasi, job involvement, job enrichment, job enlargement, dan lain-lain. Dan jumlah sampel yang diambil juga disarankan untuk lebih banyak karena sampel sejumlah 50 responden tidak dapat mengeneralisasikan keseluruhan populasi.

\section{DAFTAR PUSTAKA}

Agusta Sheilla. (2012). Analysis the Effect of Employee empowerment on Commitment in PT Tirta Investama. Atmajaya:Jakarta

Akbar, S.W., Yousaf, M., Haq, N.U. \& Hunjra, A.I. (2011) Impact of Employee Empowerment on Job Satisfaction: An Empirical Analysis of Pakistani Service Industry Interdisciplinary Journal of Contemporary Research In Business, 2(11), 680-685

Allen, N.J., \& Meyer J.P (1997). Commitment in Workplace: Theory, Research, and Application (California:SAGE Publication)
Byar, Llyoyd L \& Lestie W. Rue (2008). Human Resource Management $\left(9^{\text {th }} \mathrm{ed}\right)$. New York: McGraw-Hill

Dickson, Kevin E. \& Lorenz, A (2009). "Psychological empowerment and job satisfaction of temporary and part time nonstandard workers : A premilinary investigation" Institute of Behavioral and Applied Management, Vol 10. No. 2 .Ghozali, I (2005). Aplikasi Analisis Multivariate dengan Program SPSS (3 ${ }^{\text {rd }}$ Ed). Semarang: Badan Penerbit Universitas Diponegoro.

Greenberg, J. \& Baron, R.A. (2008), Behaviour in organization ( $9^{\text {th }}$ Ed). New Jersey: Pearson Prentice Hall

Istijanto (2010). Riset Sumber Daya Manusia. Jakarta:PT Gramedia Pustaka Utama

Ivancvich, J. M., Konopaske, R., \& Mattenson, M. T. (2005). Organizational Behavior and Management $\left(7^{\text {th }}\right.$ ed.) New York: McGraw-Hill Company

Kreitner, R., Kinicki, A. (2010). Organization Behavior $\left(9^{\text {th }}\right.$ ed). New York: McGrawHill

Lind, D.A., Marchal, W.G. \& Wathen, S.A. (2005) Statistical Techniques in Business And Economics. New York: McGraw Hill

Mas'ud, F (2004). Survai Diagnosis Organizational konsep dan aplikasi. Semarang: UNDIP

Nelson, D \& Quick, J. (2003). Organizational Behaviour: Human Behaviour at work. New York: McGraw Hill

Nelson, D \& Quick, J. (2009). Principles of Organizational Behavior: Realities and Challenges. New York: McGraw-Hill

Newstorm, J., \& Davis, K (2002). Organizational Behavior:Human Behavior at Work. New York: McGraw-Hill.

Noe, R.A., Hollenbeck, J.R., Gerhart, B., \& Wright, P.M. (2007). Fundamentals of 
Human Resource Management ( $2^{\text {nd }}$ ed). New York: McGraw-Hill.

Noe et al. (2010). Human Resource Management:Gaining Competitive Advantage. New York:McGraw-Hill

Nurgiyantoro, B. Gunawan \& Marzuki (2004). Statistik terapan. Yogyakarta:Gajah Mada University Press.

Pelit, E \& Ozturk, Y \& Arslanturk, Y (2011). "The Effect of Employee Empowerment on Employee Job Satisfaction. International Journal of Contemporary Hospitality Management." Vol 23, no 6
Rivai, V., \& Segale, J. (2010). Management Sumber Daya Manusia untuk Perusahaan ( $2^{\text {nd }}$ ed). Jakarta: Rajawali Pers.

Robbins, S.P. (2009). Organizational Behavior. New Jersey: Prentice Hall Inc.

Schemerhorn, J.R. (2010) Introduction to Management $\left(10^{\text {th }}\right.$ ed). United States:John Wiley \& Sons.

Sekaran, Uma. (2006). Metodologi Penelitian Untuk Bisnis. Jakarta:Salemba Empat

Supranto, J (2003). Metode Riset dalam Pemasaran. Jakarta: Rineka Cipta.

Uyanto, S (2009). Pedoman Analisis Data SPSS. Yogyakarta: Graha Ilmu 